\title{
Three new cecidogenous Palaeomystella Fletcher (Lepidoptera, Coleophoridae, Momphinae) associated with Melastomataceae in Brazil
}

\author{
Vitor O. Becker ${ }^{1} \&$ David Adamski
}

${ }^{1}$ Reserva Serra Bonita, P.O. Box 001, 45880-970 Camacan, Brazil; becker.vitor@gmail.com.br

${ }^{2}$ Department of Entomology, National Museum of Natural History, P.O. Box 37012, Smithsonian Institution, Washington, D.C. 20013-7012, USA; dadamski@ sel.barc.usda.gov

\begin{abstract}
Three new cecidogenous Palaeomystella Fletcher (Lepidoptera, Coleophoridae, Momphinae) associated with Melastomataceae in Brazil. Three new cecidogenous Palaeomystella Fletcher (Lepidoptera, Coleophoridae, Momphinae), described herein, induce galls on stems and leaves of Melastomataceae species. They include: Palaeomystella tibouchinae sp. n., on Tibouchina barbigera (Naudin) Baillon, P. oligophaga sp. n., on Macairea radula (Bonpland) de Candolle and M. thyrsiflora de Candolle, and P. henriettiphila sp. n., on Henriettea succosa (Aublet) de Candolle. Adults, including male and female genitalia, larva, pupa, and galls are illustrated and described in detail.
\end{abstract}

KEYWORDS: Gall-inducers; Melastomataceae; Microlepidoptera.

\begin{abstract}
RESUMO. Três espécies novas de Palaeomystella Fletcher (Lepidoptera, Coleophoridae, Momphinae), cecidógenas, associadas com Melastomataceae no Brasil. As espécies de Palaeomystella aqui descritas induzem cecídeas nos ramos e folhas de espécies de Melastomataceae: Palaeomystella tibouchinae sp. n. em Tibouchina barbigera (Naudin) Baillon, P. oligophaga sp. n. em Macairea radula (Bonpland) de Candolle, e M. thyrsiflora de Candolle, P. henriettiphila $\mathbf{s p .} \mathbf{n}$. em Henriettea succosa (Aublet) de Candolle. Os adultos, incluindo venação das asas, e genitálias dos machos e fêmeas, larvas, pupas e cecídeas, são descritos e ilustrados em detalhes.
\end{abstract}

PALAVRAS-CHAVE. Indutores de cecídeas; Melastomataceae; Microlepidoptera.

The Melastomataceae are known hosts for many gallinducing insects and other arthropods. Tavares (1917), described 29 galls associated with various species of Melastomataceae collected from the mountains near Nova Friburgo, in the state of Rio de Janeiro, Brazil. He also discovered that over one-third of these galls were induced by lepidopterous larvae. Although, many of the reared adults were badly damaged by mold from high humidity; his brief diagnoses of the adult moths indicate that they belonged to the Momphinae (Coleophoridae). Houard (1933) described over 80 galls on Melastomataceae from tropical America, making it the most common host family for gall-inducing organisms, except for the Leguminosae and Compositae. He, like Tavares, was impressed by the high incidence of lepidopterous gallinducers. Lima (1945), reported two kinds of galls induced by lepidopterous larvae on the leaves of Tibouchina sp. collected from mountainous Teresópolis, in the State of Rio de Janeiro, Brazil. Although Lima proposed that adults reared from these galls belong to Walshia (Cosmopterigidae), his illustrations of the wing venation and male genitalia indicate that these specimens are close congeners within the Momphinae. The purpose of this study is to describe three closely related species of Momphinae (Coleophoridae) reared from galls on plants of the Melastomataceae from eastern Brazil. In addition, immature stages of these moth species are described as well as the galltypes that they induce.

\section{MATERIALS AND METHODS}

Galls were located and photographed in the field, and a few were periodically opened to check for larval development. When galls were found harboring pupae, they were taken into the laboratory for the rearing of adults so that accurate associations could be made with immature stages and the adult stage. Gross morphological observations and measurements of the adult, larva, and pupa were made using a dissecting microscope (reflected light) with a calibrated micrometer. The Methuen Handbook of Colour (Kornerup and Wanscher 1978) was used as a color standard. The holotypes are deposited in the Museu Nacional, Rio de Janeiro (MNRJ), and all paratypes in the National Museum of Natural History, Washington (USNM), the Natural History Museum, London (BMNH), and in the first author's collection [VOB]. All larvae and pupae used in this study are deposited in USNM.

Palaeomystella Fletcher, 1940

Palaeomystis Meyrick, 1931:55. Type-species: P. chalcopeda Meyrick, 1931: 55, by monotypy. Preoccupied by Palaeomystis Warren, 1894: 379 [Geometridae].

Palaeomystella Fletcher, 1940:18. Type-species: Palaeomystis chalcopeda Meyrick, 1931: 55, by monotypy [of Palaeomystis], replacement name.

The family assignment of Palaeomystella was discussed 
by Becker (1999). Although it is not certain that the three species described herein are congeneric with Palaeomystella, there is little doubt that they belong to the Momphinae. We thus tentatively place these species in Palaeomystella.

\section{Palaeomystella tibouchinae sp. n.}

(Figs. 1, 4-6, 13-22)

Diagnosis. P. tibouchinae possesses typical momphine characters, but its closest relative within Palaeomystella is difficult to determine because of its unique features. Autapomorphies for this species include: vertex and frontal clypeus white; Sc of forewing with crossvein; costa of upper part of valva with several spatulate setae, with palmate distal margin; vesica with several stout, conical setae; eighth sternum unmodified in male; larva with densely textured with minute, apically-rounded denticles; body spindle-shaped; two SVgroup setae A2 and A6; pupa broadly arched ventrally; sclerites of midleg fused distally; and no cephalic or thoracic setae.

Description. Head: Vertex and frontoclypeus white; basal segments of labial palpus porrect, with terminal segment slightly angled upwards; outer surface of basal scale tuft (covering segments 1-2) of labial palpus yellowish brown intermixed with white scales tipped with yellowish brown, and white scales apically, terminal segment white intermixed with few yellowish-brown scales; inner surface of basal scale tuft white intermixed with few yellowish-brown scales, terminal segment white; scape of antenna white intermixed with few yellowish-brown scales, flagellomeres yellowish brown intermixed with few dark-brown scales basally, flagellomeres of distal half gradually becoming paler distally; proboscis white.

Thorax: Tegula and mesonotum white intermixed with few yellowish-brown scales. Fore and midleg brown intermixed with brown scales tipped with white along apical margin, hindleg white, with scale tuft of tibia pale yellowish brown intermixed with few yellowish-brown scales. Forewing (Figs. $1,13)$ : Length $9.2-10.3 \mathrm{~mm}(\mathrm{n}=7)$ white with yellowish brown base; a yellowish brown streak bisects wing longitudinally from base to apex, veins overlaid by yellowish-brown scales; apex and subapical area intermixed with few black scales; fringe pale brown; venation (Fig. 13): Sc with a crossvein near $1 / 2$ length; $R_{4}$ and $R_{5}$ stalked about $1 / 3$ distance from cell to apex; $M_{2}$ closer to $M_{1}$ than to $M_{3} ; M_{3}$ angled closer to $M_{2}$ basally than to $\mathrm{CuA}_{1}$, and closer to $\mathrm{CuA}_{1}$ than to $\mathrm{M}_{2}$ distally; $\mathrm{CuA}_{1}$ and $\mathrm{CuA}_{2}$ approximate, nearly parallel. Undersurface brown from cubital vein to costa brown; costa pale yellowish brown; area from costa to posterior margin pale yellowish brown. Hindwing: brownish gray; venation (Fig. 13): $\mathrm{M}_{1}$ and $\mathrm{M}_{2}$ stalked basally, near Rs; cell open; cubitus "3-branched", with $\mathrm{M}_{3}$, $\mathrm{CuA}_{1}$, and $\mathrm{CuA}_{2}$ short.

Abdomen: Transverse irregular rows of spiniform setae on terga 2-7 in both sexes. Eighth sternum unmodified (not shown).

Male genitalia (Figs. 14-15): Uncus narrow, slightly elongate, distally upturned, laterally setose, rooflike and concave ventrally; scaphium a narrow dilated band, forming two ventrally pointed hoodlike lobes above tuba analis; subscaphium, somewhat elongate, with two widened distal lobes, beneath tuba analis and within cavity formed by dilated rim of the scaphium; vinculum widened ventrally, juxta small and angular; valva divided near midlength, forming a distally widened, setose, digitate, dorsal part and a large spinelike lower part; costa of digitate part with several spatulate setae, with palmate distal margin; aedoeagus moderately long, parallelsided, vesica bearing several stout, spinelike setae.

Female genitalia (Fig. 16): Papillae anales narrowed distally, setose; apophyses posteriores about $1 / 3$ longer than apophyses anteriores; sterigma divided into a widened, bandlike tergum and a distally bilobed sternum, deeply and narrowly emarginate medially; ostium formed from a posteriorly widened antrum; antrum wider than long, slightly narrowed anteriorly, inception of ductus seminalis on anterior end; ductus bursae short, widened; corpus bursae an elongate sac, with no sclerotizations on inner wall.

Holotype ơ, BRAZIL: Distrito Federal, Brasília, 1000m, 4.x.1984, ex galls Tibouchina barbigera (V. O. Becker, 56890) (MNRJ).

Paratypes: 2 우, 으, Planaltina, $1000 \mathrm{~m}, 20 . i v .1982$, ex light ( $V$. O. Becker, 40158); 2 우, Minas Gerais, Unaí, 700m, 7.xi.1982, 3.xi.1983, ex light (V. O. Becker, 49211, 50000); ㅇ, Goiás, Alto Paraíso, 1400m, 3.x.1986, ex light (V. O. Becker, 64506); 27 o $^{\pi} 0^{\pi}, 23$ 우오, same data as holotype, but 1.x-10.xii.1984, ex galls T. barbigera; genitalia slides, $\sigma^{\pi} \sigma^{\pi}$, VOB 865 , USNM 81566, 81567, 83194, by DA [green labels]; wing slides USNM 81588, 81590, 81598, by DA [green labels] (VOB, USNM, BMNH).

Etymology: The species epithet, tibouchinae, is derived from the generic name of its plant host.

Host plant: Tibouchina barbigera (Naudin) Baillon (Melastomataceae); a small shrub, up to $1.5 \mathrm{~m}$ tall, which grows on dry, rocky areas in the Cerrado region of Central Brazil.

Gall (Figs. 4-6): Prosoplasmatic histioid; spherical, 15-20 $\mathrm{mm}$ diameter, pale green, with dense, coarse, yellowish-brown pubescence in whorls; fleshy when young, becoming hard like a nut shell when mature and dry; usually on leaf insertion with stalk or on leaf blade. Galls often form tight conglomerates up to ten galls on stalk. When split, fresh galls have a bright red inner wall surrounding a wide inner chamber, usually more than $10 \mathrm{~mm}$ wide. Larva feeds on the inner walls leaving a smooth surface. No traces of frass are found within the chamber. Pupa is loose within chamber; adult emerges through a $3 \mathrm{~mm}$ diameter operculum located opposite to the stalk, closed with a thin layer of white silk made by the larva, and protected outside by the coarse pubescence covering the gall.

Larva (Figs. 17-20): Length $5.5-8.8 \mathrm{~mm}(\mathrm{n}=9)$. Head hypognathous, frons, genal area, and posterior margin of head capsule amber, other areas of head and body pale yellowish brown, densely textured with minute, apically-rounded denticles; body spindle-shaped, with A3 - A4 widest segments, gradually narrowed distally. Thorax (Figs. 17, 20): T1 with Lgroup unisetose, L1 anterioventral to or even with spiracle, slightly longer than SV1; SV1 slightly posterior to L1; coxae approximate, V1s usually present; shield small, with SD1 beyond lateral margin and slightly anterior to L1; SD1 slightly longer than XD2 and XD1; XD1 and XD2 along margin slightly anterior to SD1; SD2 absent; XD1, XD2, and D2 about equal in 

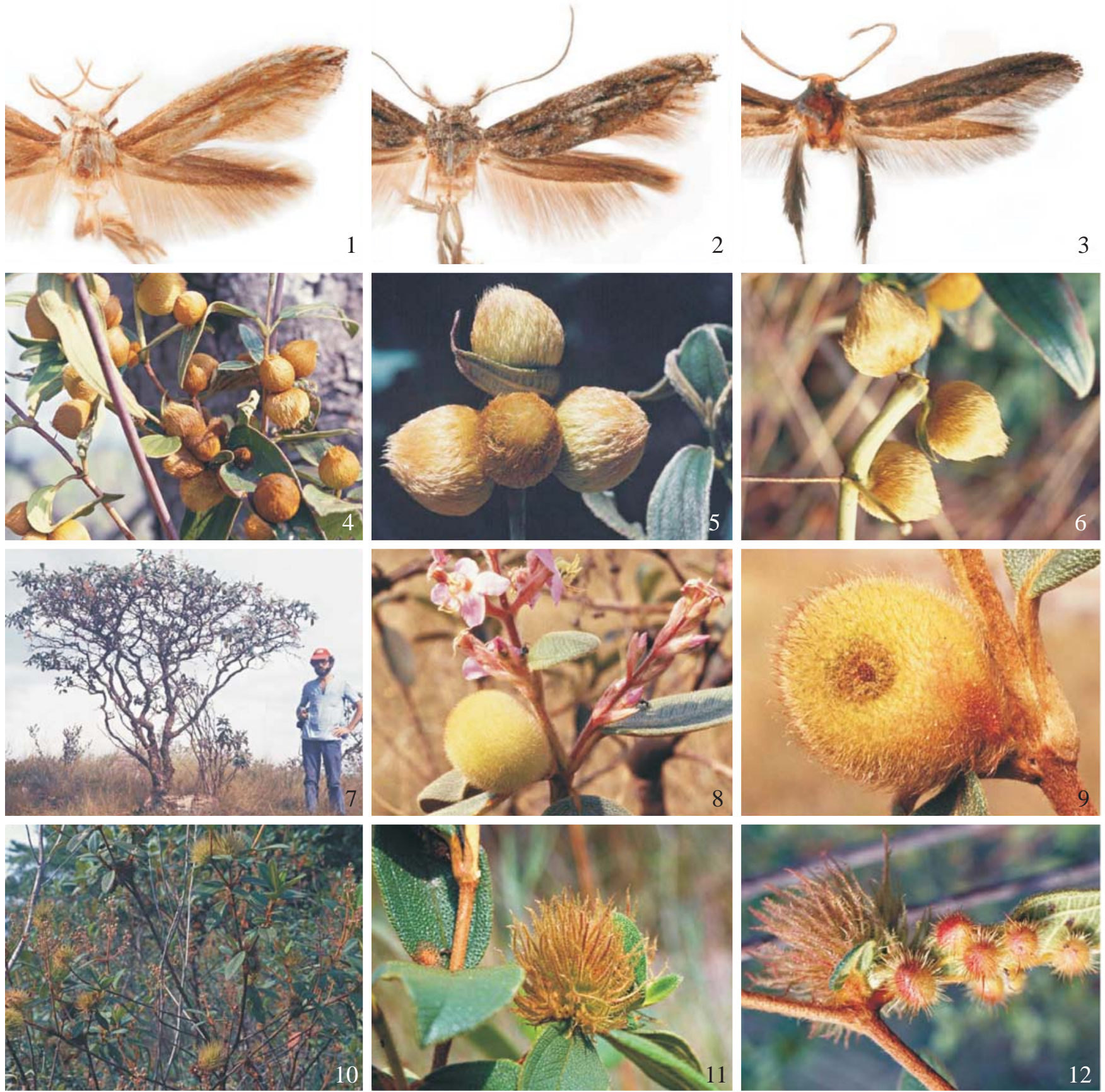

Figs. 1-12. Palaeomystella spp. 1-3, adults: 1, P. tibouchinae; 2, P. oligophaga; 3, P. henriettiphila; 4-6, galls of P. tibouchinae on stalks and leaves of Tibouchina barbigera; 7-9, Macairea thyrsiflora: 7, habitus; 8, galls of P. oligophaga on stalk (lateral view); 9, gall showing operculum; 10-12, M. radula: 10, habitus with galls of P. oligophaga; 11, gall on stalks; 12, galls on leaves.

lengths; D2 in straight line and posterior to XD1; XD1, XD2, and D2 about 4 times the length of D1; D2 equidistant between XD1 and D1; D1 near median longitudinal axis, in transverse line with or anterior to D2. T2-T3 (Figs. 17, 20): D1 short, about $1 / 2$ length of D2 and slightly posterior to SD1; SD1 about 3-4 times lengths of D1 and D2; D2 in vertical line with or slightly posterior to D1 and SD1; L1 about as long as SD1, each about 3-4 times lengths of L2 and L3, L3 dorsoposterior to L1; L1 absent in some specimens; MSD1 and MSD2 along anterior margin of segment slightly dorsal to L-group setae; SV-group unisetose; V1s usually absent. Abdomen: A1 - A2 (Figs. 1820): D1 usually absent, dorsomesal to D2 when present; SD1 dorsoposterior to spiracle, and in vertical line with or slightly posterior to L2; SD2 minute, dorsoanterior to spiracle; MD1 on anterior margin of segment; L2 slightly longer than SD1; L3 in vertical line with or slightly anterior to L2; SV-group unisetose on A1, bisetose on A2. A3 - A10 (Figs. 19-20): A3 A6 with 4 pairs of slightly protuberant prolegs, crochets biordinal and in a circle; D1s absent; SV-group bisetose; distance between V-group setae as on A1 - A2; MV3 in line or 
slightly lateral to SV1; A7 similar to previous segments, except distance between V-group setae shorter and SV2 absent; A8 with spiracle similar in size to spiracles on previous segments; A9 with paired D2, D1, and SD1 on same elongate pinaculum; D1 and SD1 about equal in size and slightly longer than D2; A10 with anal plate bearing 3 pairs of setae, D1 absent; D2 and SD2 about equal in size, and SD1 slightly longer; prolegs with several crochets in a row.

Pupa (Figs. 21-22): Length 5.8 - $9.6(\mathrm{n}=9)$. Body amber, smooth, broadly arched and slightly narrowed ventrally; sclerites of labial palpi long; sclerites of antennae widely arched anteriorly and separate, approximate and parallel from fused posterior margins of sclerites of midleg, extending to apex of forewing, covering most of the hindleg except for a small apical part; sclerites of femur of foreleg short, not extending beyond widest part of sclerites of labial palpi.

\section{Palaeomystella oligophaga $\mathbf{s p .} \mathbf{n}$.} (Figs. 2, 7-12, 23-33)

Diagnosis. P. oligophaga is closest to $P$. henriettiphila by sharing: a valva with short upper and lower parts; a modified eighth sternum in male; and pupa with sclerites of midleg not fused distally. According to the genitalia it is congeneric with P. chalcopeda and with the species reported by Lima (1945: 305), [misidentified as Walshia sp.], also reared on similar galls found on a species of Tibouchina. Autapomorphies for $P$. oligophaga include: forewing with $\mathrm{R}_{4}-\mathrm{R}_{5}$ fused; hindwing with $M_{1}$ and $M_{2}$ stalked from remnant chorda of cell; upper part of valva broadly arched or upturned; aedoeagus ventrally curved; paired bladelike signa with a semicircular base; larva with $2 \mathrm{SV}$ setae on T1; A10 with 4 pairs of setae on anal plate; and pupa with one pair of thoracic setae.

Description. Head: Vertex with white scales tipped with dark gray; frontoclypeus white; basal segments of labial palpus porrect, terminal segment slightly angled upwards; outer surface of basal scale tuft (covering segments 1-2) of labial palpus with dark-gray scales tipped with white intermixed with few white scales tipped with dark gray, terminal segment as above except, intermixed with dark gray scales; inner surface white; scape of antenna with dark-gray scales tipped with white, flagellomeres pale gray; proboscis white.

Thorax: Tegula and mesonotum with white scales tipped with dark gray intermixed with few dark-gray scales tipped with white. Legs with dark-gray scales tipped with white, scales with more white along middle, and distal apices of tibia and tarsomeres, forming bands. Forewing (Figs. 2, 23): Length 7.7 - $10.1 \mathrm{~mm}(\mathrm{n}=8)$ : pale-brown scales tipped with brown intermixed with brown scales, white scales tipped with black, and white scales tipped with brown; a narrow dark-gray streak bisects wing longitudinally from base to a brown, subapical, crescent-shaped marking, demarcated distally with dark-gray scales; longitudinal streak lined ventrally, or entirely interrupted near mid cell by a narrow streak formed by white scales tipped with dark gray; 3 raised scale tufts located posterior to cubitus; 1 in anal area, 1 in line with midcell, and 1 near tornus; apical area intermixed with black scales; venation (Fig. 23): with $\mathrm{R}_{3}$ stalked with $\mathrm{R}_{4}$ from cell, $\mathrm{R}_{5}$ absent or fused with $\mathrm{R}_{4} ; \mathrm{M}_{2}$ arched, closest to $\mathrm{M}_{3}$ at base and approximate to $\mathrm{M}_{1}$ near midlength; $\mathrm{M}_{3}$ and $\mathrm{CuA}_{1}$ parallel. Undersurface gray from area between cubitus and costa; costa pale grayish brown; area between cubitus and posterior margin pale gray. Hindwing: pale gray; venation (Fig. 23): $M_{1}$ and $M_{2}$ stalked from remnant chorda of cell from point beyond base of Rs; cell open; cubitus "3-branched", with $\mathrm{M}_{3}$ and $\mathrm{CuA}_{1}$ stalked.

Abdomen (not shown): with transverse irregular rows of spiniform setae forming large paired patches on terga 2-7 in both sexes. Eighth sternum (Fig. 26) pigmented along outer margins, laterally expanded, forming narrow arms, and anteriorly expanded medially, forming a large lobe.

Male genitalia (Figs. 24-25): Uncus elongate, angular, setose, and rooflike and concave ventrally; subscaphium an elongate lobe; vinculum a thin ring, juxta small, angular; valva divided from midlength, forming a broadly arched or upturned, setose, digitate upper part, and a smaller, straight, distally setose lower part; aedoeagus short and curved ventrally.

Female genitalia (Fig. 26): Papillae anales broadened setose lobes; apophyses posteriores slightly longer than apophyses anteriores; sterigma with tergum a thin ring, sternum developed with two broadly rounded lobes, separated by a deep, narrow notch; antrum wider than long; inception of ductus seminalis wide, slightly anterior to antrum; ductus bursae long; corpus bursae saclike, with paired signa; signa with a central bladelike invagination with a semicircular base.

Holotype $\sigma^{\pi}$, BRAZIL: Distrito Federal, Planaltina, 1000m, 11.x.1984, ex stem galls Macairea radula (V. O. Becker 56892) (MNRJ).

Paratypes: $\sigma^{\pi}$, Distrito Federal, Planaltina, 1000m, 30.xi. 1976, ex light (V. O. Becker, 39704); $50^{\pi} 0^{\pi}, 7$ 우우, Idem, 12.iv-3.v.1982, ex stem galls of $M$. radula (V. O. Becker, 40182); o*, 2 우우, Idem, 19-30. iv.1982, ex leaf galls of M. radula (V. O. Becker, 40183); $2 \sigma^{\pi} \sigma^{x}, 4$ 우우, Idem, 11.iv.1983, ex stem galls of M. radula (V. O. Becker, 40921); 3 $\sigma^{\pi} \sigma^{\pi}, 8$ 우, Idem, 3-11.x.1983, ex stem galls of M. radula (V. O. Becker, 41490); $33 \sigma^{\pi} \sigma^{x}, 26$ 우우, same data as holotype, but 1-19.x.1984, ex stem galls of M. radula; 우, Idem, 25.ix.1985, ex light (V. O. Becker, 57962); $38 \sigma^{x} \sigma^{x}, 41$ 우으, Goiás, Alto Paraíso, 1400m, 9.x-12.xi.1985, ex stem galls of M. thyrsiflora (V. O. Becker, 64501); $3 \sigma^{\pi} \sigma^{\pi}$, Idem, 1721.x.1985, ex leaf galls M. thyrsifolia (V. O. Becker 64502); $2 \sigma^{\pi} 0^{\star}$, Idem, 3.x.1985, ex light (V. O. Becker, 64504); 4 우 이, Idem, 1-6.xi.1996, ex light (V. O. Becker 98866); genitalia slides $0^{\pi} \sigma^{\pi}$ VOB 583, 584, USNM 81568, 83195, by DA [green labels], 우우 USNM 81569, 83196, by DA [green labels]; wing slides USNM 81589,81597 , by DA [green labels] (VOB, USNM, BMNH).

Etymology: The species epithet, oligophaga, is derived from oligophagous, meaning, feeding only on a small number of host species.

Host plants: Macairea radula (Bonpland) de Candolle, M. thyrsiflora de Candolle (Melastomataceae). M. radula is a bushlike perennial, up to $2 \mathrm{~m}$ in height, profusely branched (Fig. 10), that grows in marshy areas in the Cerrado region of Central Brazil. M. thyrsiflora (Fig. 7) is another bushlike perennial, up to $4 \mathrm{~m}$ tall, and is found usually in dry, disturbed habitats along roadsides, at about $1,400 \mathrm{~m}$, the highest points found in the Cerrado region of Central Brazil.

Gall (Figs. 8-12): Prosoplasmatic histioid. Three different types of soft, fleshy galls are induced by this species. Two types on M. radula, and one type on M. thyrsiflora. On the first species larva induces a large gall (Fig. 11) on stems and 

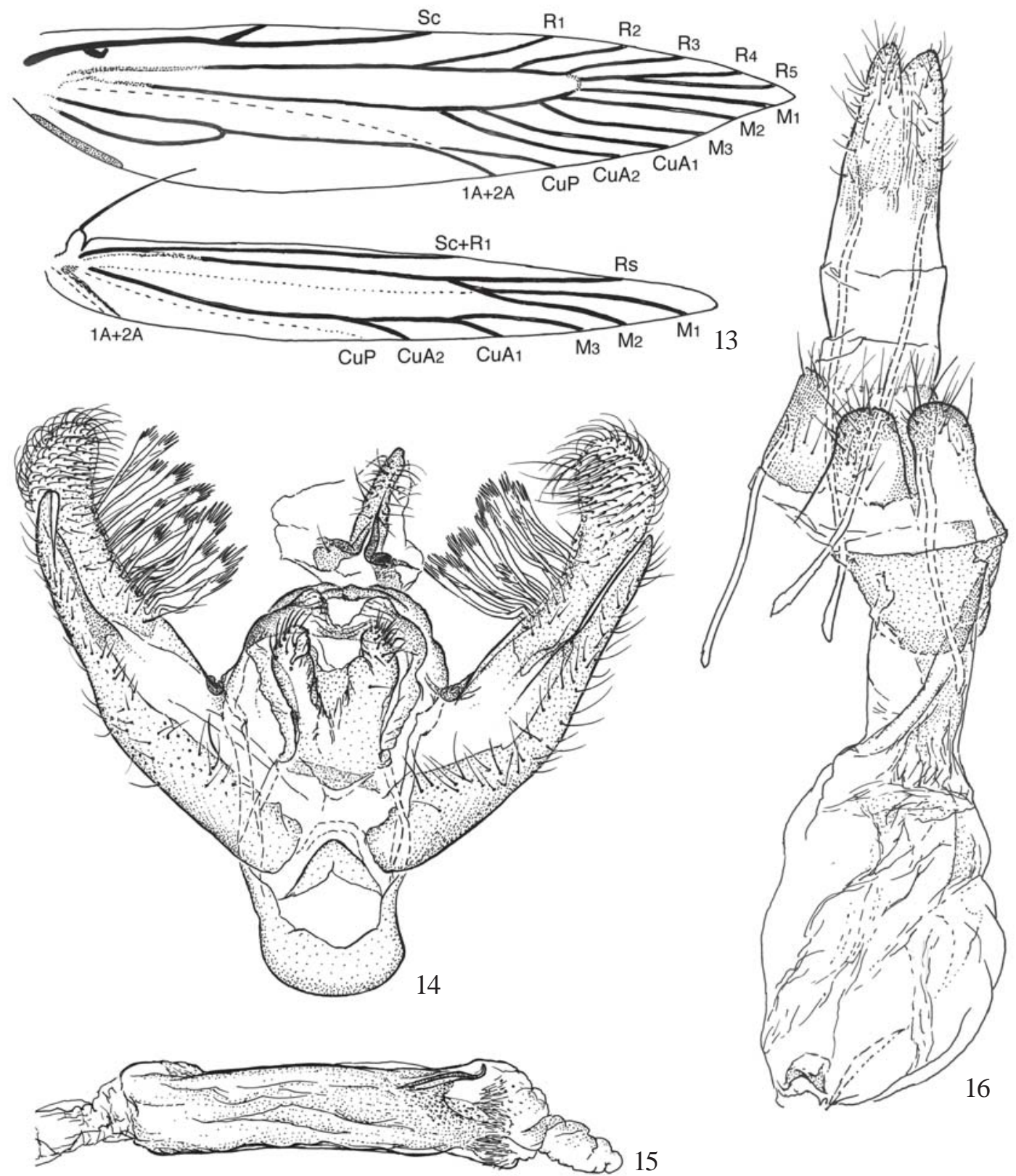

16

Figs. 13-16. Palaeomystella tibouchinae: 13, wing venation; 14, male genital capsule; 15, aedoeagus; 16, female genitalia.

branches at the base of leaves and flowers, and a small gall (Fig. 12) on the lower surface of the leaf blade. The large gall is spherical to oblong about $10-15 \mathrm{~mm}$ in diameter, pale green, pink to dark reddish brown on the side exposed to sun light; densely covered with long, tentacle-like projections, about 23 times the diameter of the gall. These projections are covered with glands that excrete a sticky exudate. The small gall is oblong, about 6-7 mm in length, pale green to pinkish red. In the small gall, the wall is thin, and the larva eats most of the tissue. The gall on $M$. thyrsoflora (Figs. 8,9) is spherical, about 15-25 $\mathrm{mm}$ in diameter, with a rough surface devoid of any projections. Most of these galls are pale green, but some can be pale yellow and pink. They are very conspicuous, from a distance looking like green peaches. The inner tissue of all three gall forms is white. The two large types on both host plants have relatively small inner chambers that are usually smaller than the length of the pupa. Consequently, the larva pupates with the head directed towards the operculum. Otherwise, the adult would not emerge from the gall. There apparently is no preference regarding the position of the operculum, as they are found in different places on the galls. No frass was found inside any of the gall types, however, some of the large stem galls on $M$. radula were occupied by larvae of an undescribed species of gelechiid, which usually feeds on leaves, and incorporate the frass in the larval chamber.

Larva (Figs. 28-31): Length 5.2 - $8.7 \mathrm{~mm}(\mathrm{n}=4)$. Head hypognathous, head capsule amber, other body regions pale gray. Thorax (Figs. 28, 31): T1 with L-group bisetose, L2 about 

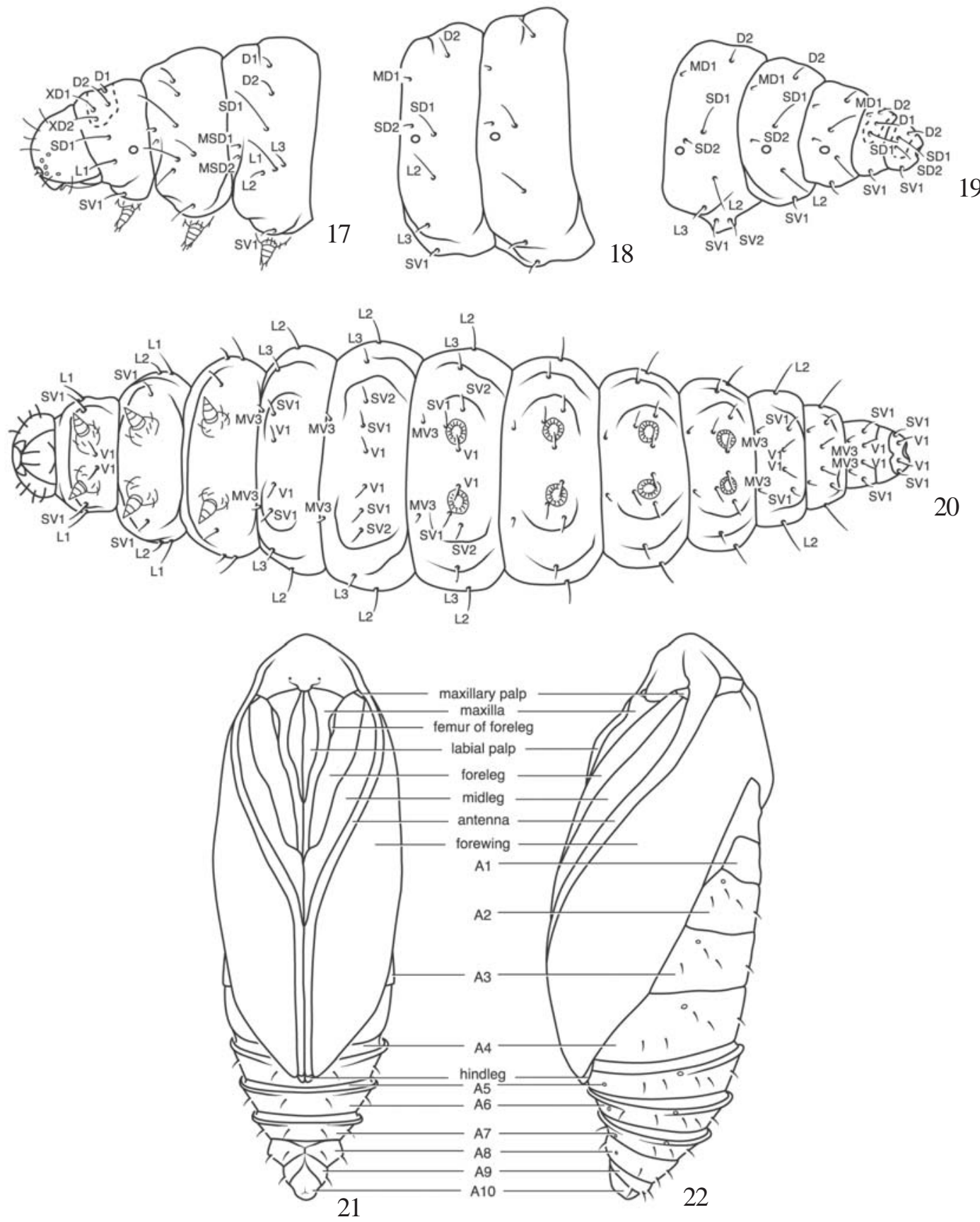

Figs. 17-22. Palaeomystella tibouchinae. 17-20, Larva: 17, head and thorax (lateral view); 18, A1-A2 (lateral view); 19, A6-A10 (lateral view); 20 , ventral view; 21-22, pupa: 21 , ventral view; 22 , lateral view.

twice length of L1; SV-group bisetose, SV1 slightly longer than SV2; coxae approximate, V1s usually present (difficult to see); shield with SD1 and XD2 along anterior margin, XD1 slightly posterior; SD1 and XD2 about equal in lengths, slightly longer than XD1; XD2 slightly closer to SD1 than to XD1; SD2 and D1 about $1 / 2$ length to above setae, posteromesal to SD1; D2 about as long as SD1 and XD2, between XD2 and $\mathrm{XD} 1$ along posterior margin; D1 and SD2 anteriomesal to D2. T2 - T3 (Figs. 28, 31): D2 about 2-3 times longer than D1; SD1 about 2-3 times longer than SD2, D1 and SD2, D2 and SD1 about equal in lengths; L-group slightly anterior to SV1; L1 about twice as long as L2 and L3; V1s on T3 slightly farther apart then V1s on T2 (difficult to see). Abdomen: A1 - A2 (Figs 29, 31): D2 about twice length of D1; SD1 slightly longer than L2, both in vertical line and posterior to spiracle; L3 slightly dorsoposterior to and about $1 / 2$ length of L1; SV and V-group setae unisetose. A3 - A10 (Figs. 31-31): A3 - A6 with 4 pairs of slightly protuberant prolegs, crochets uniordinal and in a circle; D2 about twice length of D1; SD1 about equal in length and slightly anterior to or in vertical line with D2; L1 equal in length and in vertical line with L3; L2 about $1 / 2$ length of L1 and L3; L3 dorsoposterior to SV1; SV and V-group setae unisetose; 

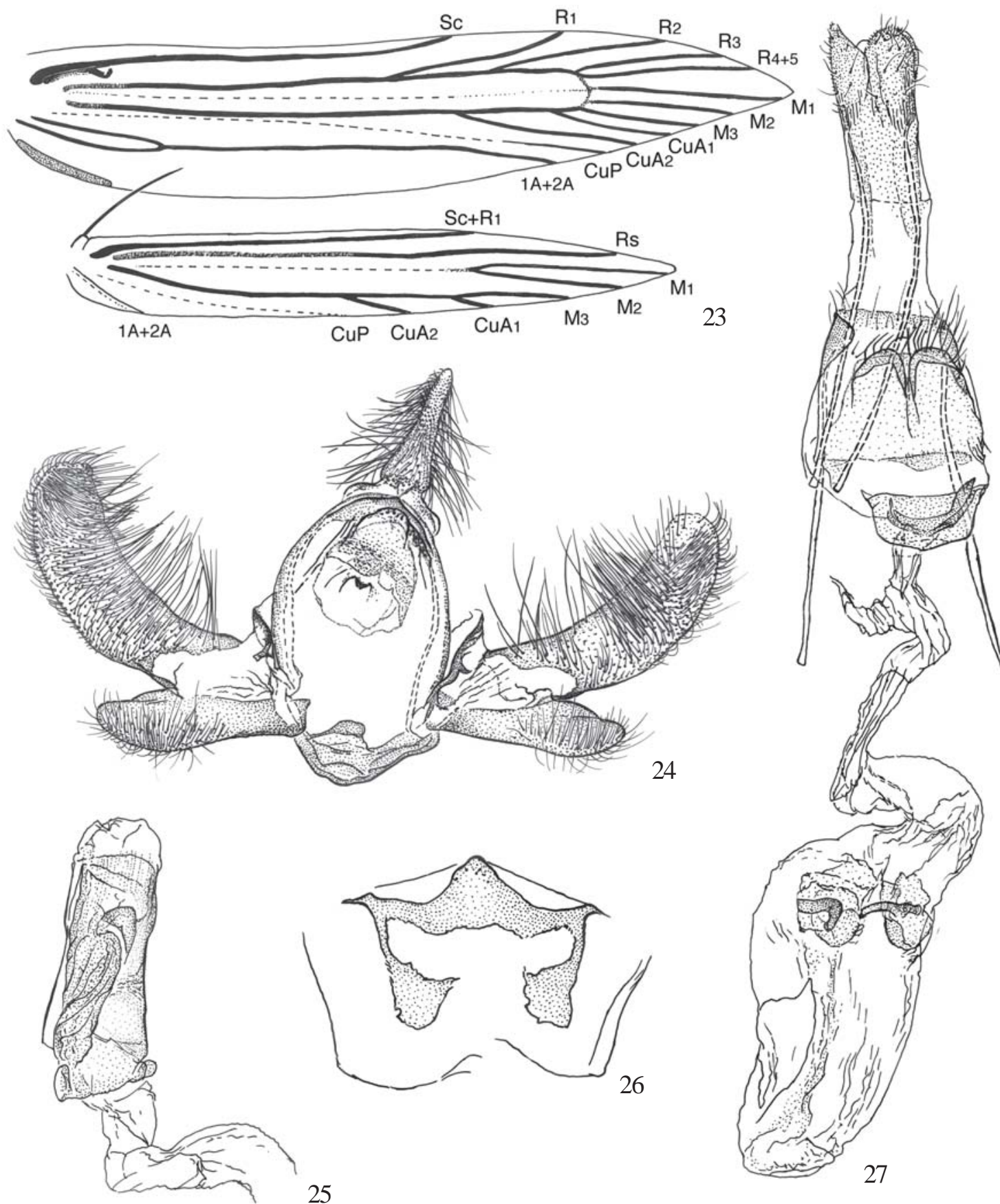

Figs. 23-27. Palaeomystella oligophaga: 23, wing venation; 24, male genital capsule; 25, aedoeagus; 26, eighth sternum; 27, female genitalia.

A7 as above except, L2 absent; A8 with size of spiracle equal to that of spiracles on previous segments; SD1 and L1 in vertical line, slightly posterior to spiracle; L3 in vertical line with L1, SV1, and V1; L2 absent. A9 with D2 posterior to D1; SD1, SV1, and V1 in straight line; anal plate on A10 with SD1 about twice lengths of D2, SD2, and D1; prolegs with several crochets in a row.

Pupa (Figs. 32, 33): Length $7.3-9.9 \mathrm{~mm}(\mathrm{n}=42)$. Body amber, smooth, shallowly arched and slightly narrowed ventrally; sclerites of labial palpi long; sclerites of antennae widely arched anteriorly and separate, approximate and parallel from used distal margins of sclerites of maxillae; sclerites of maxillae extending distally between sclerites of midleg; sclerites of midleg not fused distally; sclerites of femur of foreleg extending slightly beyond widest part of sclerites of labial palpi.

\section{Palaeomystella henriettiphila sp. $\mathbf{n}$.}

(Figs. 3, 34-44)

Diagnosis. $P$. henriettiphila is closest to $P$. oligophaga by sharing: a valva with short upper and lower parts; a modified eighth sternum in male; and pupa with sclerites of midleg not 

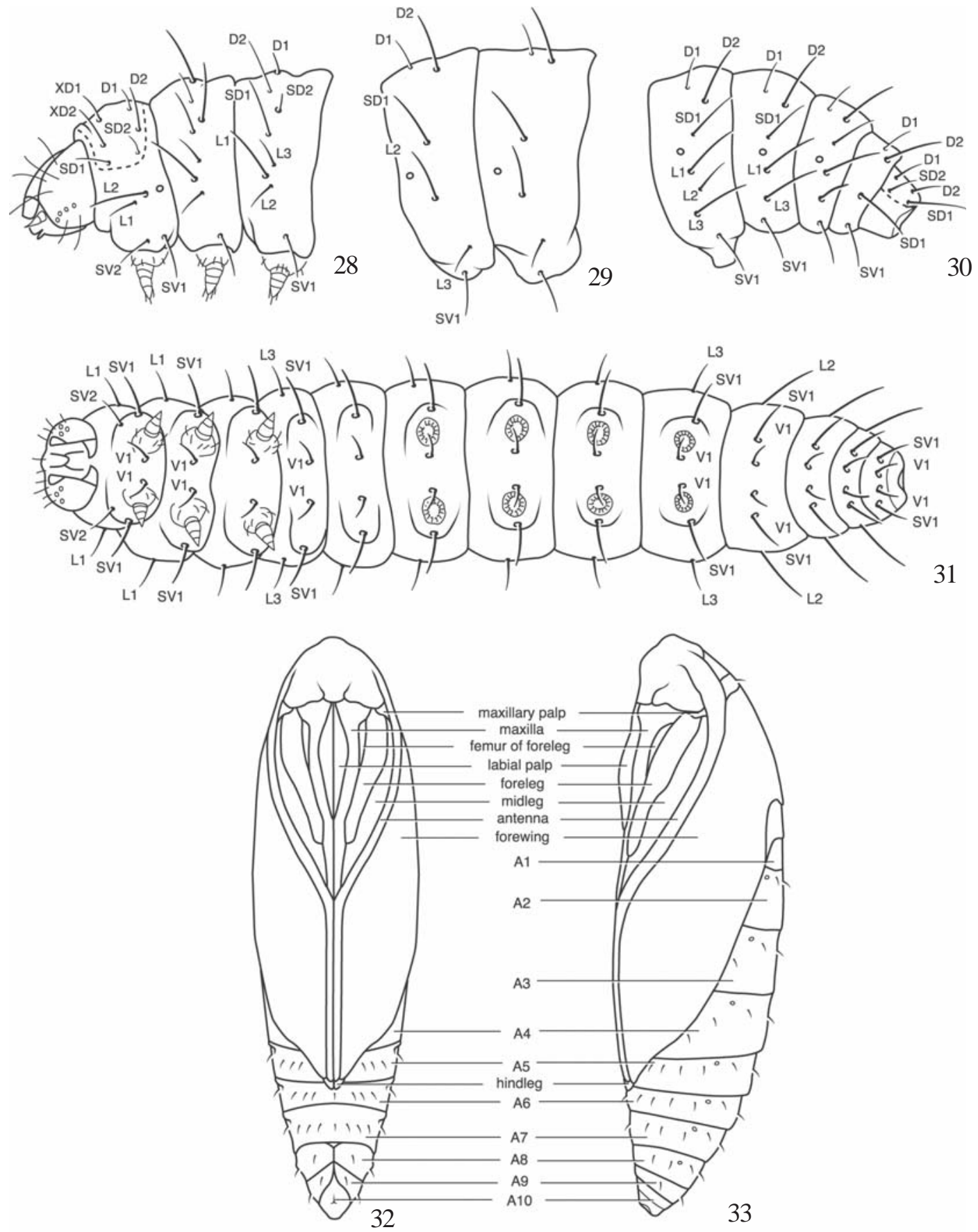

Figs. 28-33. Palaeomystella oligophaga. 28-31, Larva: 28, head and thorax (lateral view); 29, A1-A2 (lateral view); 30, A6-A10 (lateral view); 31 , ventral view; 32-33, pupa: 32 , ventral view; 33, lateral view.

fused distally. Autapomorphies for P. henriettiphila include: a green iridescence from body scales; eighth sternum with a short, narrow, medial flange on anterior margin, in male; a large angular subscaphium; base of lower part of valva dilated and circular, distally angular; antrum narrow; and pupa with two pairs of thoracic setae.

Description. Head: Vertex and frontoclypeus dark brownish gray with a green iridescence; labial palpus short, porrect, dark brownish gray with green iridescence, inner surface pale brownish yellow; scape as above, flagellomeres gradually becoming paler to distal end; proboscis short, pale brownish yellow.

Thorax: Tegula and mesonotum dark brownish gray with a green iridescence. Legs as above, tibia of hindleg with a dense covering of scales, extending ventrolaterally beyond tibial spurs and distally beyond tarsomeres 4-5. Forewing (Figs. 3, 34): Length $7.3-9.2 \mathrm{~mm}(\mathrm{n}=4)$ dark brownish gray with a green iridescence. Undersurface as above but paler; venation 


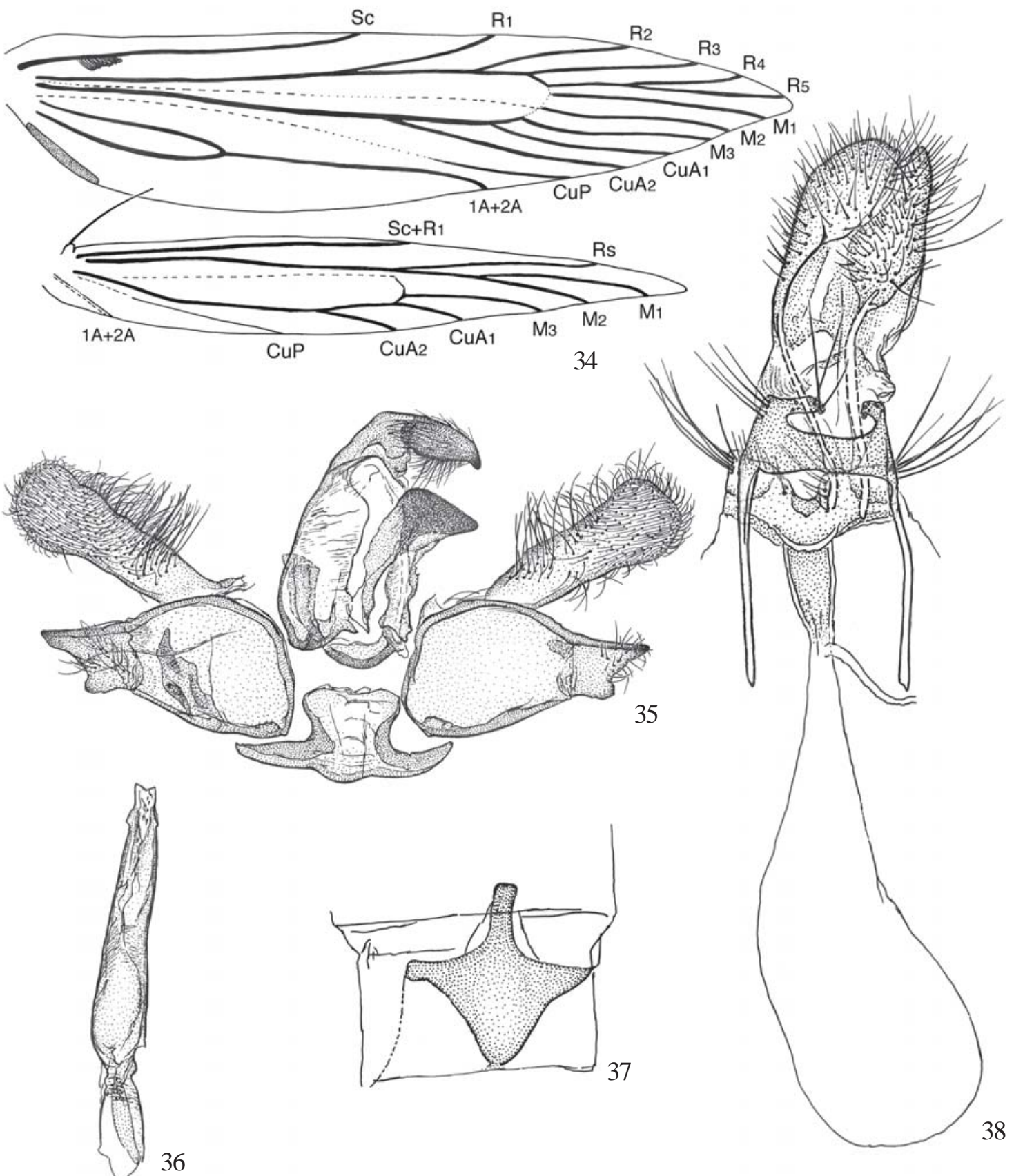

Figs. 34-38. Palaeomystella henriettiphila: 34, wing venation; 35, male genital capsule; 36, aedoeagus; 37, eighth sternum; 38, female genitalia.

(Fig. 34): $\mathrm{R}_{4}$ and $\mathrm{R}_{5}$ stalked about $1 / 2$ distance from cell to apex; $M_{1}-M_{3}$ about equidistant apart, base of $M_{2}$ a weak chorda within cell; base of $\mathrm{CuA}_{1}$ closer to $\mathrm{M}_{3}$ than to $\mathrm{CuA}_{2}$. Hindwing slightly paler than forewing; venation (Fig. 34): $M_{1}$ and $M_{2}$ stalked about $1 / 3$ distance between cell and apex, $M_{3}$ stalked from distoposterior part of cell, near $\mathrm{CuA}_{1}$; cubitus "3branched".

Abdomen: with transverse irregular rows of spiniform setae on terga 2-7 in male and in female (not shown). Eighth sternum in male (Fig. 37) with a short, narrow, medial flange on anterior margin, widening posterolaterally, forming two arms; posterior margin forming a triangular lobe with a rounded apex.

Male genitalia (Figs. 35, 36): Uncus laterally flattened, setose, with a downcurved apical part; ventral arms of tegumen upcurved, fused to a large angular subscaphium; vinculum and juxta fused; valva divided, upper part forming a wide, setose, digitate lobe, lower part somewhat elliptical in shape, extending ventrodistally, forming an angular, sparsely setose, part; aedoeagus gradually narrowed distally, vesica with several stout, conical setae.

Female genitalia (Fig. 38): Papillae anales elongate, setose lobes; apophyses posteriores curved, about as long as 

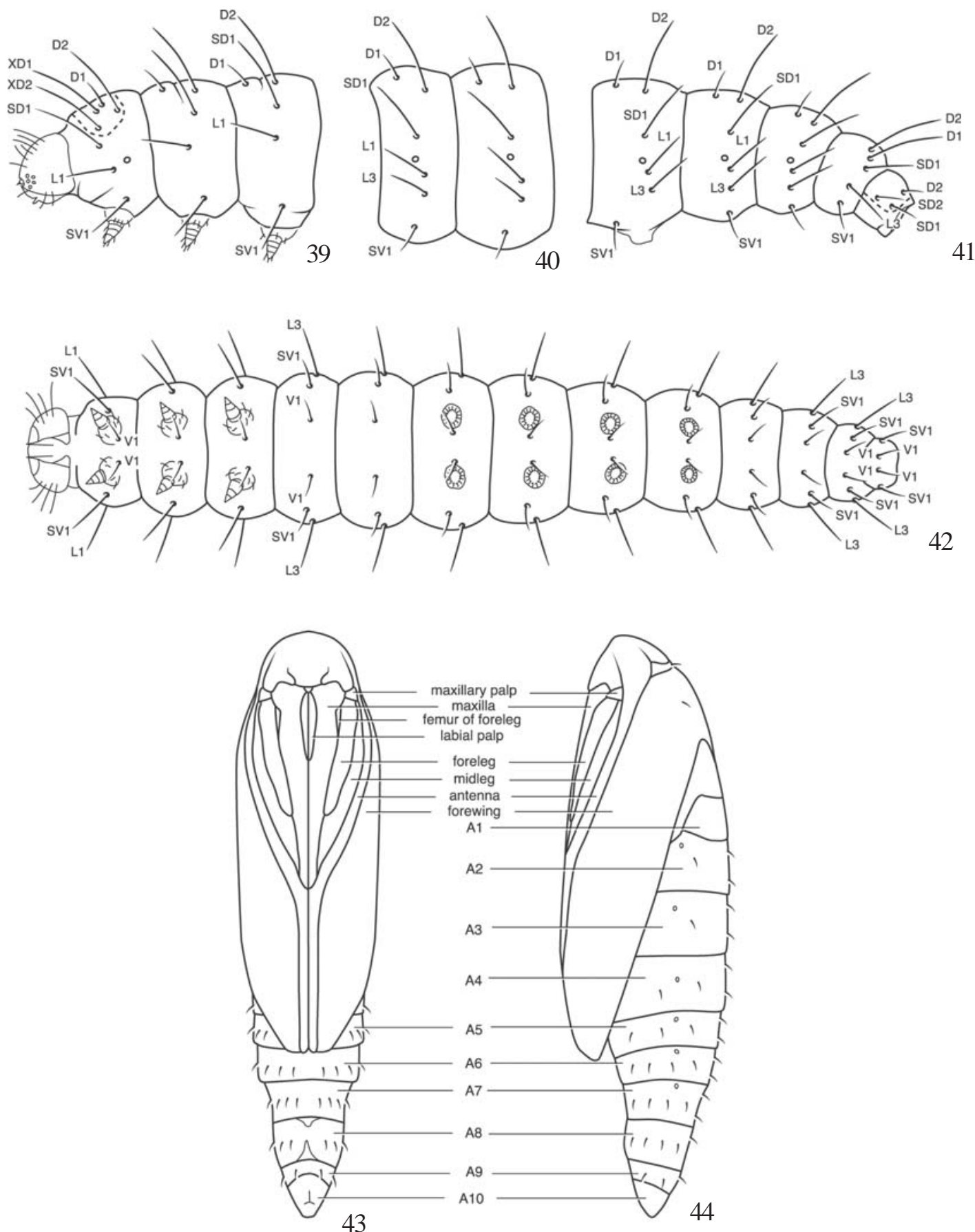

Figs. 39-44. Palaeomystella henriettiphila. 39-42, larva: 39, head and thorax (lateral view); 40, A1-A2 (lateral view); 41, A6-A10 (lateral view); 42, ventral view. 43-44, pupa: 43 , ventral view; 44, lateral view.

apophyses anteriores; eighth tergum of sterigma with a transversely emarginated lamella postvaginalis within posterior half, emargination partially enclosed by two inwardly pointed, free lateral arms; eighth sternum deeply notched medially on posterior margin, extending anteriomedially around ostium, forming antrum of the ductus bursae; antrum longer than wide, inception of ductus seminalis on anterior end; corpus bursae an elongate sac, with no sclerotizations on inner wall.
Holotype, $\sigma^{x}$, BRASIL: Alagoas, Ibateguara, 400 m, 10-20.iii.1994, ex larvae on "carrasqueira", Henriettea succosa (V. O. Becker, 90937) (MNRJ).

Paratypes, $40^{\pi} 0^{\pi}, 3$ 우 9 , same data as holotype, genitalia slides, B\& USNM 5612, 83192, by DA [green label]; \& USNM 5614, 5615, by DA [green label]; wing slide USNM 81599, by DA [green label].

Etymology: The species epithet, henriettiphila, is derived from the generic name of its host species.

Host plant: "carrasqueira", Henriettea succosa (Aubl.) DC. 
Gall: Cataplasmatic histioid; cauline, fusiform hypertrophy of the tip of branches.

The internodes are extremely reduced, with the leaves packed together, forming a rosette, looking like a small cabbage.

Larva (Figs. 39-42): Length 4.6 - $5.6 \mathrm{~mm}(\mathrm{n}=6)$. The following description is based upon early instar larvae. Head hypognathous, body smooth, head capsule amber, other body regions pale gray. Thorax (Figs. 39, 42): T1 with L-group unisetose; SV unisetose, SV1 about equal in length and slightly posterior to L1; coxae approximate, V1s usually present (difficult to see); shield small, SD1 beyond lateral margin and slightly anterior to L2 and XD2; SD2 absent; XD1 slightly posterior to XD2; SD1, XD2, XD1, and D2 about equal in lengths, nearly 2-3 times the length of D1; D1 closer to XD1 than to D2. T2 - T3 (Figs 39, 42): D2 2-3 times length of D1; SD1 about equal in length and in vertical line with D2, L1 slightly anterior to above setae; SV-group setae unisetose; V1s slightly farther apart than V1s on T1 (difficult to see). Abdomen: A1 A2 (Figs. 40, 42): D2 about 2-3 times longer than D1; SD1 slightly shorter than D2, in vertical line with or slightly posterior to spiracle; SD2 absent; L1 about as long as SD1, in vertical line with or slightly anterior to D2; L3 slightly shorter than and in vertical line with L1; L2 absent; SV1 slightly anterior to L3, about twice length and in line with V1; A3 - A10 (Figs. 41-42): A3 - A6 with 4 pairs of slightly protuberant prolegs, crochets uniordinal and in a circle; SV-group unisetose, SV1 anterior to proleg and about $1 / 2$ length of L1; V1s in line with or slightly anterior to L3; A7 as above except, all setae in a vertical line; A8 as above, spiracle about same size as spiracles on previous segments; A9 with all setae in about straight line; anal plate on A10 with SD1 and SD2 equal in lengths, slightly longer than D2, SD2 absent; prolegs with several crochets in a row.

Pupa (Figs. 43, 44): Length 9.9 - $10.1 \mathrm{~mm}(\mathrm{n}=7)$. Body amber, smooth, shallowly arched and slightly narrowed ventrally; sclerites of labial palpi short; antennal sclerites widely arched anteriorly and separate, approximate and parallel beyond fused distal margins of sclerites of maxillae, extending between and to apices of forewings; distal part of hindlegs not visible; sclerites of maxillae extending posteriorly between sclerites of midleg; sclerites of midleg not fused distally; sclerites of femur of foreleg short, extending beyond widest part of sclerites of foreleg.

\section{DISCUSSION}

The differences in shapes and sizes of galls induced by P.oligophaga is clear evidence that these characters are controlled by the host plant. Furthermore, it appears that shape, size and color of the galls can be independently controlled by the different organs on the same plant. The date of collecting of adults at light, as well as their of emergence from the galls indicate that both $P$. tibouchinae and P. oligophaga are bivoltine, with one generation developing through the wet season and the other generation developing through the dry season; with adults emerging [mating and laying eggs], at the beginning and at the end of wet season respectively.

Larvae of Momphinae have been characterized by having two L-group setae on T1 (Stehr, 1987; Wagner et. al., 2004). In this study, we observe a reduction in the number of L-group setae (from a bisetose to a unisetose condition) and a reduction in the number of setae on the anal plate (from 4 pairs to 3 pairs) in P. tibouchinae and in P. henriettiphila. In addition, a loss of D1s in P. tibouchinae, and losses a an L-group seta on A1 A9, and a reduction in the size of the prolegs and associated crochets has been observed for all three species described herein. These setal losses appear to be correlated with a reduction in area and pigmentation of the prothoracic shield and anal plate, and lack of body pinacula.

Reductions of the sizes of prolegs, crochets, sclerotized pinacula, and numbers of setae are well documented in the Lepidoptera, and appear to be associated with endophagous feeding habits of the larva (Dugdale, per. Comm., cited in, Brown et al., 2004).

Acknowledgments. We thank Antônio L. L. Gomes, EMBRAPACPAC, Planaltina, Distrito Federal, Brazil, for helping with the rearing, and for preparing the specimens; Sueli M. Sato, of the above institution, for the identification of the host plants; Kuniko Arakawa of Ibaraki, Japan, for the illustrations of the wing venation, and male and female genitalia; Diana Marques of Lisbon, Portugal, for the illustrations of the larvae and pupae; and James F. DiLoreto and John S. Steiner, Office of Imaging and Photographic Services, Smithsonian Institution, Washington, DC, for scanning original artwork, digital production of plates, and photography of adult specimens.

\section{REFERENCES}

Becker, V. O. 1999. Family reassignments and synonymy of some taxa of Neotropical Microlepidoptera. Revista Brasileira de Zoologia 16: $141-170$.

Brown, J. W.; J. Baixeras; J. A. Solórzano-Filho \& J. E. Kraus. 2004. Description and life history of an unusual fern-feeding tortricid moth (Lepidoptera: Tortricidae) from Brazil. Annals of the Entomological Society of America 97: 865-871.

Fletcher, T. B. 1929. A list of generic names used for the Microlepidoptera. Memoirs of the Department of Agriculture of India (Entomology) 11: 1-244.

Houard, C. 1933. Les zoocécidies des plantes de l'Amérique du Sud et de l'Amérique Centrale. Paris, Hermann, 519 p.

Kornerup, A. \& J. H. Wanschner. 1978. Methuen Handbook of Colour. $2^{\text {nd }}$ ed. London, Methuen, 243 pp.

Lima, A. da Costa. 1945. Insetos do Brasil. $5^{\circ}$ Tomo. Lepidópteros, $1^{\text {a }}$ Parte. Rio de Janeiro, Escola Nacional de Agronomia. Série didática $\mathrm{n}^{\circ}$ 5. $379 \mathrm{p}$.

Meyrick, E. 193. Cosmopterygidae [sic!] Oecophoridae, Heliodinidae. Exotic Microlepidoptera 4: 51-56, 116-126, 174-176.

Stehr, F. W. 1987. Momphidae. In Stehr, F.W., ed. Immature Insects. Dubuque, Iowa, Kendall-Hunt, 754 pp.

Tavares, J. S. 1917. As cecídias do Brazil que se criam nas plantas da família das Melastomataceae. Broteria, Series Zoologica 15: 18-40.

Wagner, D.; D. Adamski \& R. L. Brown. 2004. A new species of Mompha Hübner (Lepidoptera: Coleophoridae: Momphinae) from buttonbush (Cephalanthus occidentalis L.) with descriptions of the early stages. Proceedings of the Entomological Society of Washington 106: $1-18$.

Warren, W. 1894. New genera and species of Geometridae. Novitates zoologicae 1: $366-466$. 